\title{
Potassium Channel
}

National Cancer Institute

\section{Source}

National Cancer Institute. Potassium Channel. NCI Thesaurus. Code C17008.

Ion channel selective for potassium ions. There are several types, each with different functions. 